Marquette University

e-Publications@Marquette

Biological Sciences Faculty Research and

Publications

Biological Sciences, Department of

$1-1-2008$

\title{
The Spinobulbar System in Lamprey
}

James T. Buchanan

Marquette University, james.buchanan@marquette.edu

James F. Einum

Marquette University

Accepted version. Brain Research Reviews, Vol. 57, No. 1 (January 2008): 37-45. DOI. (C) 2008 Elsevier. Used with permission. 


\title{
The Spinobulbar System in Lamprey
}

\author{
James T. Buchanan \\ Department of Biological Sciences, Marquette University, \\ Milwaukee, WI \\ James F. Einum \\ Department of Biological Sciences, Marquette University, \\ Milwaukee, WI
}

\begin{abstract}
Locomotor networks in the spinal cord are controlled by descending systems which in turn receive feedback signals from ascending systems about the state of the locomotor networks. In lamprey, the ascending system consists of spinobulbar neurons which convey spinal network signals to the two descending systems, the reticulospinal and vestibulospinal neurons. Previous studies showed that spinobulbar neurons consist of both ipsilaterallyand contralaterally-projecting cells distributed at all rostrocaudal levels of the spinal cord, though most numerous near the obex. The axons of spinobulbar neurons ascend in the ventrolateral spinal cord and brainstem to the caudal mesencephalon and within the dendritic arbors of reticulospinal and vestibulospinal neurons. Compared to mammals, the ascending system in lampreys is more direct, consisting of excitatory and inhibitory monosynaptic inputs from spinobulbar neurons to reticulospinal neurons. The spinobulbar neurons are rhythmically active during fictive locomotion, representing a wide range of timing relationships with nearby ventral root bursts including those in phase, out of phase, and active during burst transitions between opposite ventral roots. The spinobulbar neurons are not simply relay cells because they can have mutual synaptic interactions with their reticulospinal neuron targets and they can have synaptic outputs to other spinal neurons. Spinobulbar neurons not only receive locomotor inputs but also receive direct inputs from primary mechanosensory neurons. Due to the relative simplicity of the
\end{abstract}


NOT THE PUBLISHED VERSION; this is the author's final, peer-reviewed manuscript. The published version may be accessed by following the link in the citation at the bottom of the page.

lamprey nervous system and motor control system, the spinobulbar neurons and their interactions with reticulospinal neurons may be advantageous for investigating the general organization of ascending systems in the vertebrate.

Keywords: lamprey, spinal cord, locomotion, spinobulbar, reticulospinal

\section{Introduction}

A general organizational feature of locomotor systems is a descending command system to control the locomotor networks and an ascending feedback system to inform the descending systems about the state of the locomotor networks. The descending system provides signals that start and stop the locomotor networks, control turning and the speed of locomotion, and provide postural adjustments to maintain orientation of the body with respect to gravity and light. During fictive locomotion, the ascending feedback system provides a rhythmic "efference copy" to the descending neurons that will alter the output characteristics of the descending neurons, transforming tonic inputs into phasic outputs and providing the proper timing of the descending signals with respect to locomotion (Orlovsky et al. 1999).

The lamprey nervous system has proven useful for investigating the structure and function of the spinal locomotor networks and of the descending control of the spinal cord because the lamprey brainstem and spinal cord are somewhat simpler compared to higher vertebrates (Buchanan 2001). Progress has also been made characterizing the ascending system of lamprey, and the spinobulbar neuron component of this system will be reviewed here.

\section{Descending systems in lamprey}

Before considering the ascending system in lamprey, a brief review of the descending systems is necessary. The descending systems in lamprey consist of $\sim 2400$ bulbospinal neurons. Most of these ( 2000) originate from the reticular nuclei (Swain et al. 1993), which are the mesencephalic reticular nucleus (MRN) and three rhombencephalic nuclei (anterior, middle, and posterior rhombencephalic reticular nuclei or ARRN, MRRN, and PRRN, respectively). The other descending system in lamprey is the vestibulospinal system consisting of $\sim 400$ neurons located in the

Brain Research Reviews, Vol. 57, No. 1 (January 2008): pg. 37-45. DOI. This article is (C) Elsevier and permission has been granted for this version to appear in e-Publications@Marquette. Elsevier does not grant permission for this article to be further copied/distributed or hosted elsewhere without the express permission from Elsevier. 
intermediate and posterior octavomotor nuclei and projecting only to the rostral spinal cord (Bussières et al. 1999). In lamprey, as in other lower vertebrates, there are uniquely identifiable reticulospinal neurons, the Müller cells (Kimmel 1993; Murakami et al. 2004). These neurons have relatively constant positions and morphologies from animal to animal (Rovainen 1967) allowing identification in electrophysiological experiments. Mapping studies of the synaptic outputs of Müller cells have shown that they make direct excitatory connections to neurons of the proposed locomotor network (Rovainen 1974a; Buchanan 1982) as do many other reticulospinal (RS) neurons (Ohta and Grillner 1989). Stimulation of the reticular formation (Guertin and Dubuc 1997; Wannier et al. 1998) or even single Müller cells (Buchanan and Cohen 1982) during fictive swimming has powerful influences on the swimming rhythm including changing the speed and symmetry of ventral root bursts on the two sides of the spinal cord as observed in turning behavior (McClellan and Hagevik 1997). Reticulospinal neurons are active during actual swimming and other motor behaviors, often firing rhythmically, as shown with extracellular axonal recordings in the intact lamprey (Zelenin 2005).

New insight into the function of the reticulospinal system in lamprey was obtained using stimulation of individual reticulospinal neurons during fictive locomotion with spike triggered averaging of ventral root firing (Zelenin et al. 2001; Deliagina et al. 2002; Zelenin et al. 2003). Bilateral recordings of dorsal and ventral branches of the ventral roots, supplying dorsal and ventral myotomal muscles, revealed at least 20 patterns of excitatory and inhibitory effects on these four ventral root branches (Zelenin et al. 2001). These patterns could be grouped into functional motor synergies that are likely to compose the basic elements of motor control of the lamprey body, which lacks lateral fins.

\section{Ascending systems in mammals}

During actual or fictive locomotion and scratching in mammals, neurons of various descending systems in the brainstem exhibit rhythmic modulation of their membrane potentials that are synchronous with either the flexion or extension phase of the cycle (Orlovsky 1970a; Orlovsky 1972a,b; Arshavsky et al. 1978c,d;

Brain Research Reviews, Vol. 57, No. 1 (January 2008): pg. 37-45. DOI. This article is (C) Elsevier and permission has been granted for this version to appear in e-Publications@Marquette. Elsevier does not grant permission for this article to be further copied/distributed or hosted elsewhere without the express permission from Elsevier. 
Arshavsky et al. 1988). This rhythmic activity is dependent upon the cerebellum, as the rhythm is in large part abolished by cerebellar ablation (Orlovsky 1970b; Arshavsky 1978c,d). It is known that locomotor input to the cerebellum originates from the spinocerebellar system, which includes the dorsal spinocerebellar tract (DSCT), the ventral spinocerebellar tract (VSCT), and the spinoreticulocerebellar pathway (SRCP). The DSCT appears to be specialized for conveying sensory information (Arshavsky et al. 1972a; Bosco and Poppele 2001). The VSCT and SRCP convey information regarding the activity of the spinal interneurons involved in generating motor patterns (Lundberg 1971; Arshavsky et al. 1972b; Arshavsky et al. 1978a,b) although they also receive some sensory inputs (Lundberg and Weight 1971). This rhythmic feedback signal regarding the state of the locomotor networks is important for ensuring that descending control signals for various motor programs occur with the proper timing during the locomotor rhythm. For example, if a running cat encounters an obstacle requiring a jump, the descending command to jump must occur in the appropriate phase of the step cycle (Arshavsky and Orlovsky 1986).

\section{Ascending locomotor signals in lamprey}

As in cat, reticulospinal neurons in lamprey exhibit rhythmic membrane potential oscillations during fictive locomotor activity. This was first shown in the isolated brainstem - spinal cord preparation in which fictive locomotion was induced by brief electrical stimulation of the spinal dorsal columns or a cranial nerve (Kasicki and Grillner 1986; Kasicki et al. 1989). The rhythmic activity of reticulospinal neurons was generally in phase with the ipsilateral spinal ventral roots, though the Mauthner cells, which have decussating axons, were in phase with contralateral ventral roots. Rhythmic activity was found in neurons at all levels of the reticular formation, though tending to weaken at more rostral levels, especially in the MRN (Kasicki and Grillner 1986). In contrast with the cat studies, however, ablation of the cerebellum in the lamprey had little effect on the rhythmic activity of reticulospinal neurons (Kasicki et al. 1989).

An unresolved issue from these initial lamprey studies was the source of the rhythmic activity in the reticulospinal neurons. Two

Brain Research Reviews, Vol. 57, No. 1 (January 2008): pg. 37-45. DOI. This article is (C) Elsevier and permission has been granted for this version to appear in e-Publications@Marquette. Elsevier does not grant permission for this article to be further copied/distributed or hosted elsewhere without the express permission from Elsevier. 
candidates are 1) ascending input from the spinal cord and 2) possible rhythm-generating networks within the brainstem. To examine the contribution of ascending signals from the spinal cord to the rhythmic activity, Dubuc and Grillner (1989) constructed a diffusion barrier over the rostral spinal cord to separate the preparation into a spinal cord bath and a brainstem bath. Fictive locomotion was induced in the spinal cord bath by application of NMDA to the physiological saline. Under these conditions, the reticulospinal neurons still exhibited rhythmic membrane potential oscillations, demonstrating that ascending signals from the spinal cord contribute to this rhythmic activity (Dubuc and Grillner 1989). Similar results were obtained for the other descending system in lamprey, the vestibulospinal neurons (Bussières and Dubuc 1992). The amplitude of the activity in reticulospinal neurons in the split-bath experiments was smaller than that observed under conditions in which both the brainstem and spinal cord were active during the initiation of locomotion (Kasicki et al. 1989), suggesting either that there are local rhythm-generating networks in the brainstem or that with brainstem participation, the spinal cord activity is more intense compared to the activity induced with NMDA, leading to more robust ascending signals. Motoneurons do have a greater amplitude of oscillation during brainstem-induced fictive swimming compared to glutamate-induced fictive swimming (Buchanan and Kasicki 1995) but whether locomotor rhythmgenerating networks are present in the lamprey brainstem has not been resolved.

A recent study of the rhythmic activity in reticulospinal neurons in the split-bath preparation revealed that while most cells are in phase with ipsilateral ventral roots as previously reported, about $25 \%$ of reticulospinal neurons exhibit rhythmic activity in phase with the contralateral ventral roots (Einum and Buchanan 2005). This finding of a diversity of locomotor phases among reticulospinal neurons suggests that there is specificity in the inputs of spinobulbar neurons to reticulospinal cells. Whether this specificity is constant or changes with conditions (e.g., behavioral context) is not yet known. However, under the restricted conditions of the isolated brainstem - spinal cord preparation, the specificity of ascending inputs appears to be a characteristic of individual reticulospinal neurons as shown from recordings of uniquely identified Müller cells (Fig. 1).

Brain Research Reviews, Vol. 57, No. 1 (January 2008): pg. 37-45. DOI. This article is (C) Elsevier and permission has been granted for this version to appear in e-Publications@Marquette. Elsevier does not grant permission for this article to be further copied/distributed or hosted elsewhere without the express permission from Elsevier. 


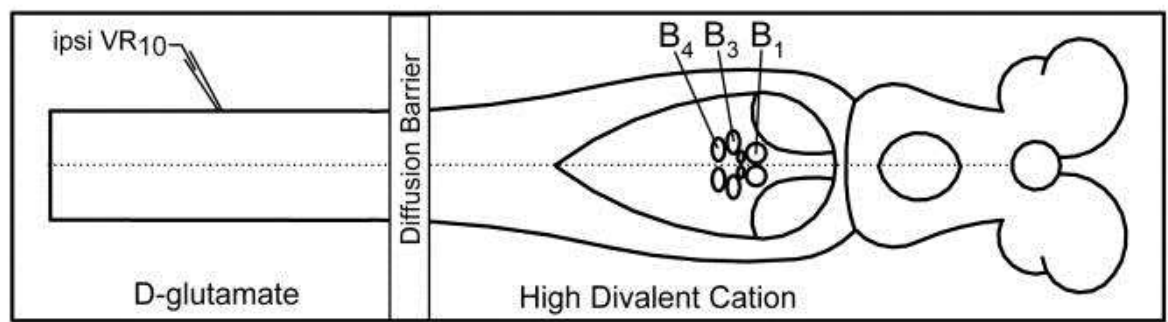

\section{Lamprey 1}
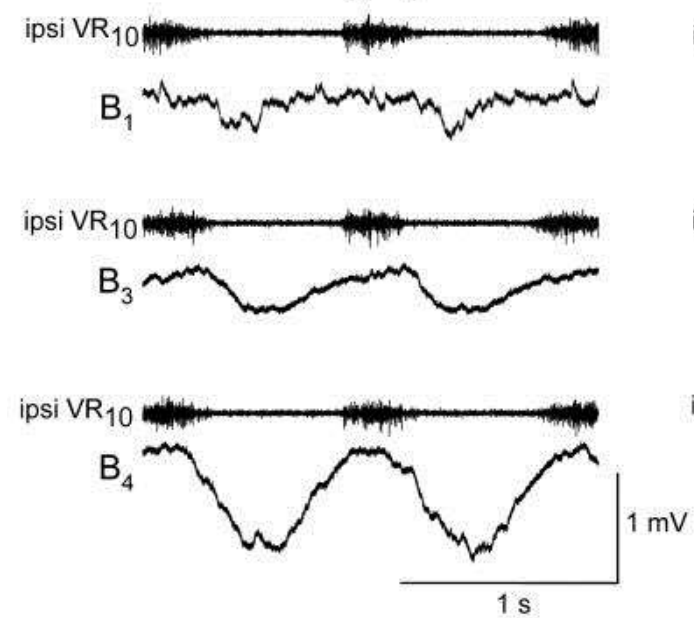
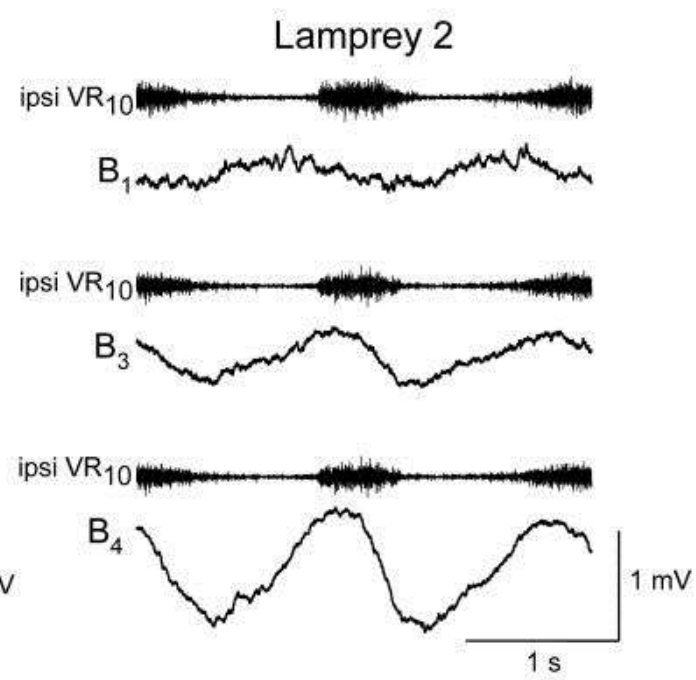

Figure 1 Similarity in the ascending inputs to uniquely identified reticulospinal neurons recorded in different animals. Intracellular recordings of membrane potential from three of the large uniquely identifiable Müller cells in the MRRN, B1, B3, and B4, in a split bath preparation in which the spinal cord was exposed to D-glutamate to induce locomotor activity and the brainstem bath was perfused with a high divalent cation solution to reduce polysynaptic pathways. The intracellular activity is referenced to the ipsilateral ventral root at spinal segment 10 . The amplitudes and shapes of the ascending rhythmic inputs are similar in the two animals.

\section{Anatomical studies of the spinobulbar system in lamprey}

The anatomical substrate for the spinobulbar system in the lamprey was first demonstrated by Ronan and Northcutt (1990). Using silver staining of degenerating spinobulbar axons to reveal their ascending course, they found that the spinobulbar axons ascend in the ventrolateral portions of the spinal cord and brainstem in the spinal lemniscus and are well within the dendritic fields of both reticulospinal and vestibulospinal neurons. The spinobulbar axons could be traced rostrally to the isthmic region, the border between the 
rhombencephalon and mesencephalon. Using retrograde labeling with horseradish peroxidase, Ronan and Northcutt (1990) found that the cell bodies of spinobulbar neurons are densest near the obex and more numerous on the contralateral side of the cord with respect to the injection site.

A later retrograde labeling study confirmed and extended the findings of Ronan and Northcutt by demonstrating that the number of spinobulbar neurons per spinal segment falls dramatically with distance from the obex but cells could be found at all rostrocaudal levels of the spinal cord (Vinay et al. 1998b). This study also confirmed that contralaterally-projecting spinobulbar neurons are more numerous than ipsilaterally-projecting spinobulbar neurons. The somata of spinobulbar neurons were found to range from small to large and were mostly located in the column of spinal grey matter. However, some cell bodies were also found in the lateral axon tracts including the edge cells (Rovainen 1974b), a class of intraspinal stretch receptors (Grillner et al. 1984).

\section{Physiological studies of spinobulbar neurons in lamprey}

The split-bath preparation as described above had shown that ascending signals from the spinal cord contribute to the rhythmic locomotor activity in reticulospinal and vestibulospinal neurons (Dubuc and Grillner 1989; Bussières and Dubuc 1992). To begin a characterization of the ascending signals in spinobulbar neurons, Vinay and Grillner (1992) used sharp intracellular microelectrode recordings of spiking activity in spinobulbar axons during fictive swimming. Ascending axons fired one to several spikes per ventral root burst with about two-thirds of the axons firing in phase with either the ipsilateral or the contralateral ventral root with respect to the axon, and the remaining third firing at the transitions between the alternating ventral root bursts of the two sides. The timing of rhythmic activity in the spinobulbar cell bodies could not be determined in this study because the location of the cell bodies was not known. In a later study, an intracellular recording from a single contralaterally-projecting spinobulbar neuron revealed that this cell was active in phase with the contralateral ventral roots (Vinay et al. 1998b).

Brain Research Reviews, Vol. 57, No. 1 (January 2008): pg. 37-45. DOI. This article is @ Elsevier and permission has been granted for this version to appear in e-Publications@Marquette. Elsevier does not grant permission for this article to be further copied/distributed or hosted elsewhere without the express permission from Elsevier. 
While it was clear from cerebellar ablation in lampreys that spinocerebellar pathways do not contribute significantly to the rhythmic activity in reticulospinal neurons (Kasicki et al. 1989), the directness of spinobulbar input to reticulospinal neurons was not known. To address this issue, intracellular recordings of reticulospinal neurons were made during electrical stimulation of the lateral spinal tracts, a procedure which should activate spinobulbar axons (Vinay et al. 1998a). Both excitatory and inhibitory responses in ipsilateral reticulospinal neurons were observed and these responses could be potentiated with trains of several pulses suggesting recruitment of additional inputs via interneuronal pathways, though whether this occurred in the spinal cord or in the brainstem was not determined. An early component of the responses persisted with high frequency stimulation (10 - $20 \mathrm{~Hz}$ ), suggesting the presence of monosynaptic connections, in addition to the oligosynaptic pathways (Vinay et al. 1998a).

Though demonstrating mono- and oligosynaptic pathways with axon tract stimulation, the Vinay et al. (1998a) study did not determine the directness of the ascending locomotor signals to reticulospinal neurons. To address this issue, Einum and Buchanan (2004) used the split-bath preparation to activate locomotion in the spinal cord and then added a high divalent cation solution to the brainstem bath to reduce polysynaptic pathways without affecting monosynaptic potentials. Addition of the high divalent cation solution produced no significant reduction in the amplitude of the rhythmic activity in reticulospinal neurons suggesting that direct synaptic input from spinobulbar neurons provides most of the rhythmic locomotor input to reticulospinal neurons that ascends from the spinal cord. In addition, it was shown that the rhythmic activity in high divalent cation solution consists of both excitatory and inhibitory components (Einum and Buchanan 2004).

\section{Intracellular recordings of spinobulbar neurons}

\subsection{Synaptic interactions}

To test for direct spinobulbar input to reticulospinal neurons, paired intracellular recordings were made between spinobulbar

Brain Research Reviews, Vol. 57, No. 1 (January 2008): pg. 37-45. DOI. This article is (C) Elsevier and permission has been granted for this version to appear in e-Publications@Marquette. Elsevier does not grant permission for this article to be further copied/distributed or hosted elsewhere without the express permission from Elsevier. 
neurons and reticulospinal neurons (Einum and Buchanan 2006). These studies revealed postsynaptic potentials (psps) produced by the spinobulbar neurons in reticulospinal neurons that met criteria for monosynaptic potentials: the psps followed high-frequency $(10 \mathrm{~Hz})$ stimulation one-for-one with constant latency and unitary shape. In addition, estimates of synaptic delay were consistent with monosynaptic connections and the psps persisted in the presence of high divalent cation solution. In addition to these clear monosynaptic psps, occasional psps that were not monosynaptic were encountered, and spinobulbar inputs to non-reticulospinal neurons within the reticular nucleus were also observed. Therefore, while indirect pathways are likely present, direct connections appear to predominate in the isolated preparation.

The paired intracellular recordings also revealed that spinobulbar input could be either excitatory or inhibitory, and this finding applied both to ipsilaterally-projecting spinobulbar neurons (iSB) and to contralaterally-projecting spinobulbar neurons (cSB). In addition, the outputs of spinobulbar neurons appeared to be selective in that a given spinobulbar neuron contacted only a subset of reticulospinal neurons (Einum and Buchanan 2006).

The paired recordings also allowed testing of outputs from the reticulospinal neurons to the spinobulbar neurons. These psps were monosynaptic, excitatory, and often of a dual electrical - chemical nature (Einum and Buchanan 2006) as shown previously for lamprey reticulospinal neurons (Rovainen 1974b). Interestingly, in about $10 \%$ of the reticulospinal - spinobulbar neuron pairs tested, mutual synaptic interactions were observed including both recurrent excitation and recurrent inhibition (Fig. 2). Mutual excitation might be expected to promote an increase in the level of excitation in brainstem and spinal cord, while recurrent inhibition would reduce excitation of the brainstem and perhaps contribute to the repolarizing phase of oscillatory activity in the reticulospinal neurons.

Brain Research Reviews, Vol. 57, No. 1 (January 2008): pg. 37-45. DOI. This article is (C) Elsevier and permission has been granted for this version to appear in e-Publications@Marquette. Elsevier does not grant permission for this article to be further copied/distributed or hosted elsewhere without the express permission from Elsevier. 

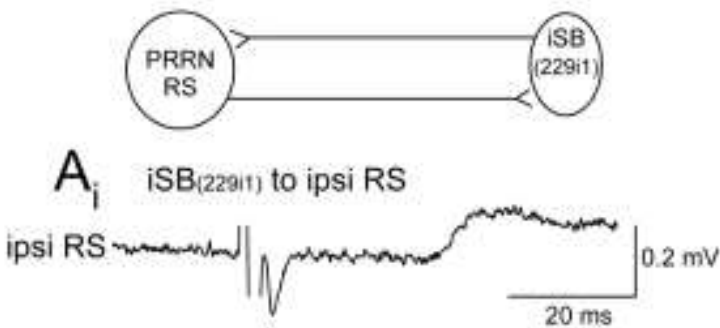

$\mathrm{A}_{\mathrm{ii}}$ ipsi RS to isB\{z2o1\}
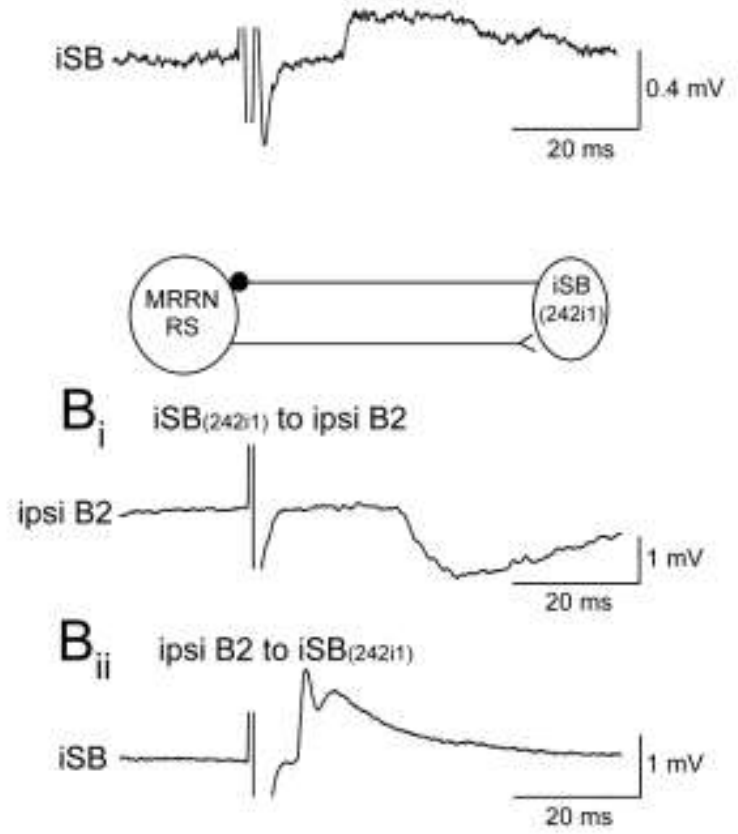

Figure 2 Examples of mutual interactions between descending reticulospinal neurons and ascending spinobulbar neurons. (A) Mutual excitation between a reticulospinal neuron in the PRRN and an ipsilateral excitatory SB neuron. (B) A Müller reticulospinal neuron that made a dual electrical - chemical excitatory synapse on an ipsilateral spinobulbar neuron was in turn inhibited by the same spinobulbar neuron. (Figure modified from Einum and Buchanan 2006).

\subsection{Morphology of spinobulbar neurons}

Intracellular injections of spinobulbar neurons with biocytin revealed a number of previously unknown features of these cells (Einum and Buchanan 2006). The sampled spinobulbar cells included both cSB ( $53 \%$ of all spinobulbar neurons tested) and iSB (44\%) neurons and also a previously unknown population of bilaterallyprojecting spinobulbar neurons (bSB) (3\%). Examples of spinobulbar neurons drawn from wholemounts of the spinal cord are shown in Fig. 3. The labeled spinobulbar neurons tended to have small- to medium-

Brain Research Reviews, Vol. 57, No. 1 (January 2008): pg. 37-45. DOI. This article is (C) Elsevier and permission has been granted for this version to appear in e-Publications@Marquette. Elsevier does not grant permission for this article to be further copied/distributed or hosted elsewhere without the express permission from Elsevier. 
sized cell bodies (mean diameter $=17 \mathrm{um}$ ) and had axonal conduction velocities (mean $=0.8 \mathrm{~m} / \mathrm{s}$ ) also typical of small lamprey neurons such as the excitatory interneurons (EIN) (Buchanan et al. 1989). About half of the CSB neurons had extensive contralateral dendrites, reminiscent of the giant interneurons, a class of CSB neurons in the caudal third of the spinal cord characterized by Rovainen (1967). Interestingly, most labeled spinobulbar neurons (80\%) had axon branch points that gave rise not only to an ascending axon branch but to a descending branch as well. This suggests that the spinobulbar neurons have synaptic outputs in the spinal cord in addition to the brainstem and this was confirmed with paired intracellular recordings (Fig. 4). The feature of bifurcating axons with ascending and descending processes in the lamprey spinobulbar neurons is similar to the C3-C4 propriospinal neurons of the cat which have an axon ascending to the lateral reticular nucleus and a descending axon that excites cervical motoneurons (Illert and Lundberg 1978). Also similar to the lamprey spinobulbar neurons, the $\mathrm{C} 3-\mathrm{C} 4$ propriospinal neurons are active during fictive locomotion (Arshavsky et al. 1986b).

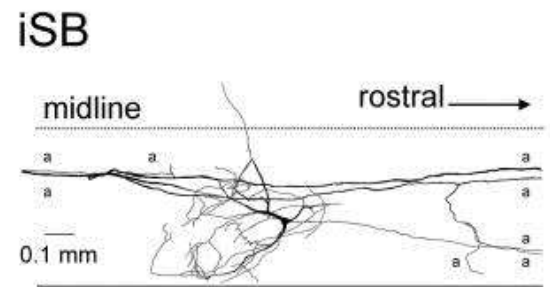

lateral edge

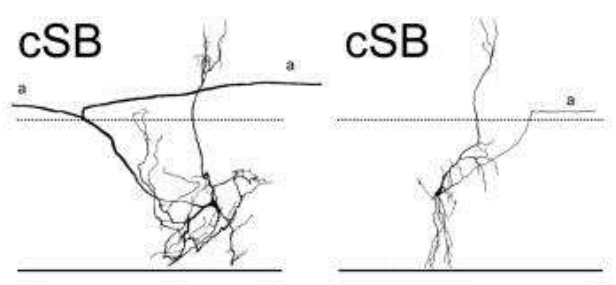

iSB

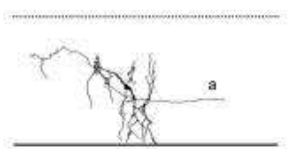

cSB

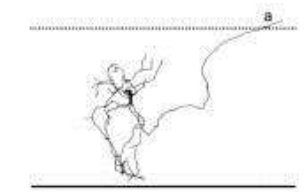

bSB
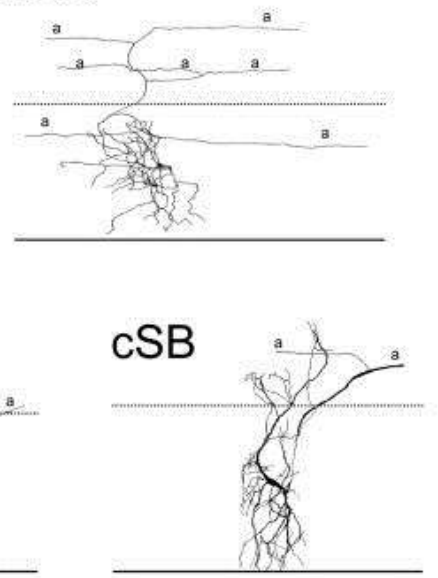

Figure 3 Examples of the morphology of spinobulbar neurons injected with biocytin, reacted with horseradish peroxidase-avidin and drawn from wholemounts of the spinal cord. iSB = ipsilaterally-projecting spinobulbar neuron; $b S B=$ bilaterallyprojecting spinobulbar neuron; $\mathrm{CSB}=$ contralaterally-projecting spinobulbar neuron; a = axon. (Figure modified from Einum and Buchanan 2006).

Brain Research Reviews, Vol. 57, No. 1 (January 2008): pg. 37-45. DOI. This article is (C) Elsevier and permission has been granted for this version to appear in e-Publications@Marquette. Elsevier does not grant permission for this article to be further copied/distributed or hosted elsewhere without the express permission from Elsevier. 

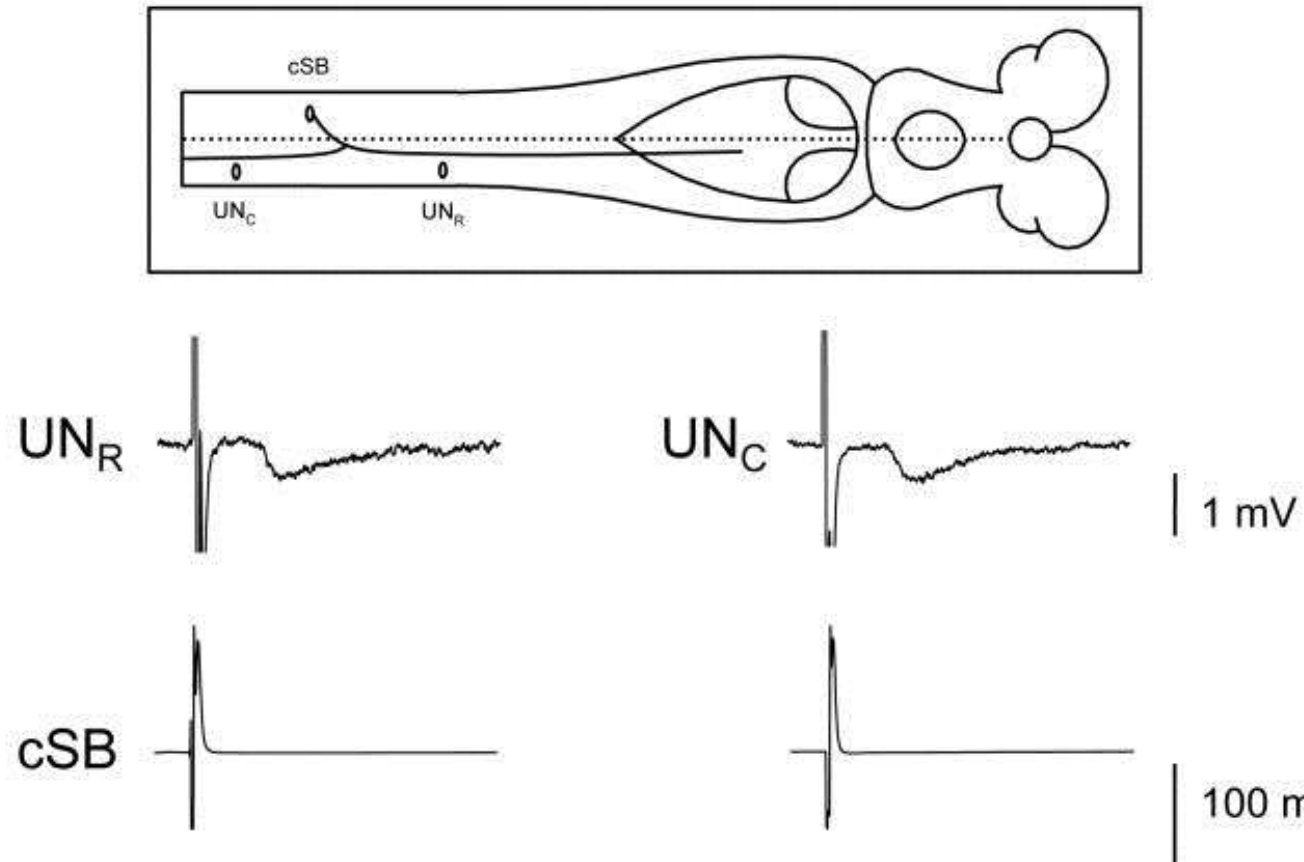

$100 \mathrm{mV}$

$20 \mathrm{~ms}$

Figure 4 Spinobulbar neurons not only have synaptic outputs in the brainstem but also within the spinal cord along both the ascending and descending axon branches. An example is shown of the output of a contralaterally-projecting spinobulbar neuron (CSB) that produced ipsps in unidentified neurons (UN) within the spinal cord both rostral and caudal to the soma of the CSB.

\subsection{Activity of spinobulbar neurons during fictive locomotion}

Somatic intracellular recordings of spinobulbar neurons during fictive swimming revealed that all of the cells had rhythmic membrane potential oscillations (Einum and Buchanan 2005). Some spinobulbar neurons reached spike threshold though most were subtheshold, as is typical of lamprey spinal neurons during fictive locomotion (Buchanan and Cohen 1982; Buchanan et al. 1989; Buchanan and Kasicki 1995). As for phase relations of the rhythmic activity in spinobulbar neurons (Einum and Buchanan 2005), all recorded iSB neurons were in phase with the nearby ipsilateral ventral root with peak depolarizations of the population occurring throughout the ventral root burst (Fig. 5A,B). The phases of the CSB neurons were more diverse including those that were in phase with the nearby ipsilateral ventral root, those in phase

Brain Research Reviews, Vol. 57, No. 1 (January 2008): pg. 37-45. DOl. This article is (C) Elsevier and permission has been granted for this version to appear in e-Publications@Marquette. Elsevier does not grant permission for this article to be further copied/distributed or hosted elsewhere without the express permission from Elsevier. 
with the contralateral ventral root, and those with peaks occurring at the transitions between ventral root bursts on the two sides (Fig. 5B). There was no correlation between the presence of contralateral dendrites in a CSB neuron and the occurrence of out of phase activity as might be expected (Einum and Buchanan 2006). The spinobulbar neurons not only received input from the locomotor network but also from primary sensory afferents. This was shown with paired intracellular recording between spinobulbar neurons and the dorsal cells, which are primary mechanosensory neurons innervating the skin with their cell bodies located in the dorsomedial region of the spinal cord. Individual spinobulbar neurons were shown to receive both monosynaptic excitatory input from dorsal cells and input from the locomotor network (Einum and Buchanan 2006).
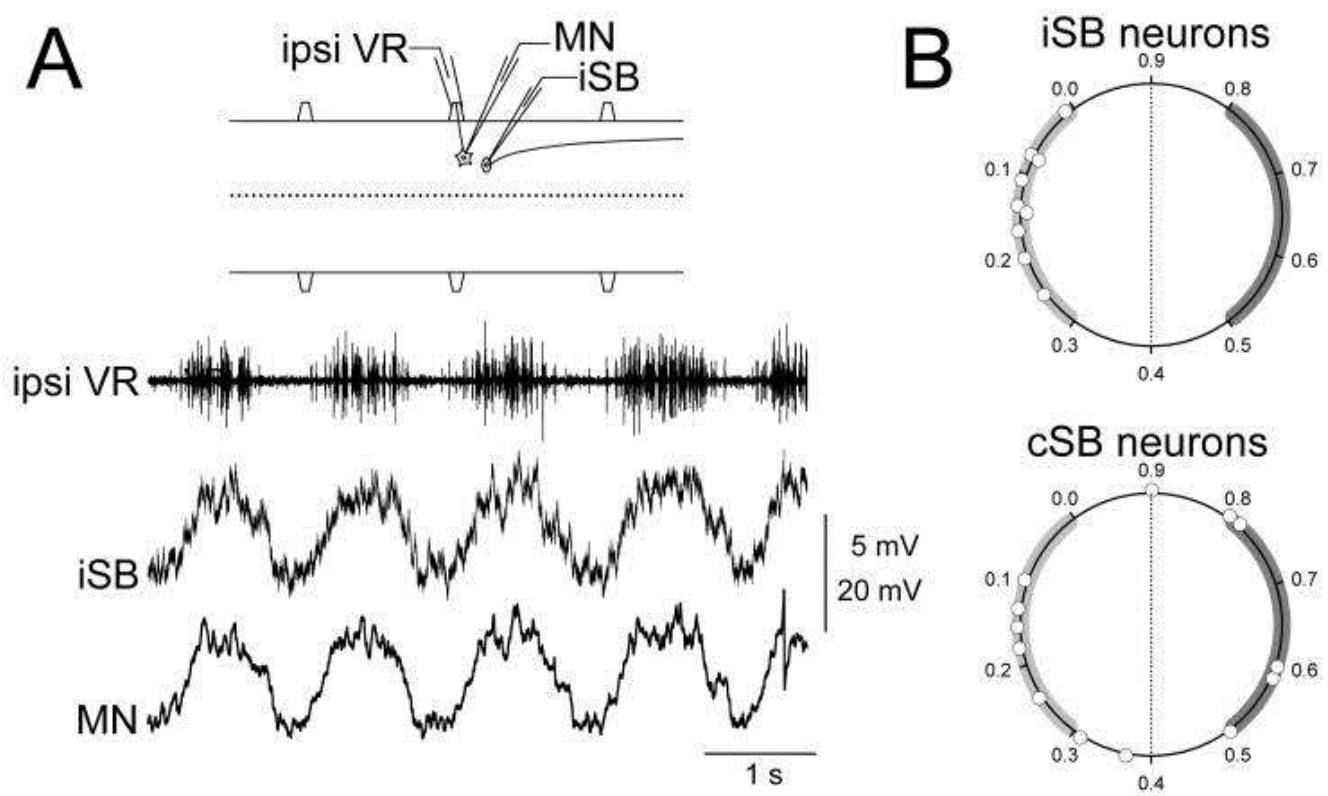

Figure 5 Rhythmic locomotor activity in spinobulbar neurons. (A) Paired recording of a motoneuron and an ipsilaterally-projecting spinobulbar neuron (iSB) in the same spinal segment during fictive swimming. The two cells had similar oscillatory envelopes and similar detailed synaptic activity. (B) Summary of timings of rhythmic activity in spinobulbar neurons. The phase of the peak depolarization of each cell is represented on a circular plot where 0.0 is the onset of the ipsilateral ventral root burst and 0.5 is the onset of the contralateral ventral root burst ( $B$ modified from Einum and Buchanan 2005).

Brain Research Reviews, Vol. 57, No. 1 (January 2008): pg. 37-45. DOI. This article is (C) Elsevier and permission has been granted for this version to appear in e-Publications@Marquette. Elsevier does not grant permission for this article to be further copied/distributed or hosted elsewhere without the express permission from Elsevier. 
NOT THE PUBLISHED VERSION; this is the author's final, peer-reviewed manuscript. The published version may be accessed by following the link in the citation at the bottom of the page.

\section{Discussion}

The presumed function of the ascending spinobulbar system is to inform the descending command systems about the state of the locomotor networks and about sensory signals generated during movements. Such network and sensory signals allow descending command signals to be coordinated with network activity and with body movements. The resulting rhythmic activity in the descending neurons will transform tonic inputs such as from the visual system or from otolith organs into a rhythmic output that will interact at a particular phase relationship with the rhythmic activity of the spinal locomotor networks. In lamprey, the precision of this timing relationship will degrade as the descending signal moves down the spinal cord (Kasicki et al. 1989). This is because the conduction velocity of most reticulospinal axons $(1-4 \mathrm{~m} / \mathrm{s})$ is faster than the propagation velocity of the swim rhythm $(0.2-1 \mathrm{~m} / \mathrm{s}$, depending on swim frequency). As the rhythmic reticulospinal signals descend, they will encounter the locomotor network in progressively shifted phases of the swim cycle. In addition, reticulospinal axons with different conduction velocities will arrive at different times at a particular segmental level. These factors will result in the loss of the timing precision of the signals with respect to the locomotor rhythm as the signals descend. Thus, it is likely that only the most rostral spinal cord $(10 \%)$ will receive the descending signals with precise timing. However, the rostral cord is the site of the beginning of each descending wave of body contraction and is therefore the most important region for controlling the nature of the wave. It is also in this most rostral region where the spinobulbar neurons are located in the highest density.

In mammals, most of the ascending signal, both sensory and network, are relayed to the descending neurons by way of the cerebellum. It has been proposed that the function of the cerebellum in this ascending feedback system is to coordinate the various motor programs or synergies that may be occurring at the same time (Arshavsky et al. 1986a). In lamprey, the cerebellum does not appear to be involved in the ascending feedback function as it can be removed with no effect on the rhythmic activity in descending neurons and the spinobulbar neurons make direct connections to the descending

Brain Research Reviews, Vol. 57, No. 1 (January 2008): pg. 37-45. DOI. This article is @ Elsevier and permission has been granted for this version to appear in e-Publications@Marquette. Elsevier does not grant permission for this article to be further copied/distributed or hosted elsewhere without the express permission from Elsevier. 
reticulospinal neurons. This difference between lampreys and mammals presumably exists because the lamprey has a far less complicated motor apparatus, lacking lateral fins, and thus using mainly differential contractions of body muscles for directional maneuvering through water. In addition, the lamprey has a less diverse array of motor programs that require coordinating (Zelenin 2005). Perhaps, then, the ascending system in lamprey accomplishes the same basic functions as the spinocerebellar system in mammals but does so in a simpler, more direct fashion.

The lamprey spinobulbar system provides the reticulospinal neurons with rhythmic locomotor signals with a wide range of timings, especially the contralaterally-projecting spinobulbar cells. The reticulospinal neurons also show a wide range of timings of their rhythmic activity related to locomotion. This diversity of ascending signals and the apparent specificity of ascending inputs to individual reticulospinal neurons suggest that individual spinobulbar neurons represent activity of specific subpopulations of the spinal networks and convey these signals to specific reticulospinal neurons. Examples of possible subpopulations that may be represented would be those interneurons controlling dorsal versus ventral myotomal muscles or those interneurons coordinating bilateral co-activation of dorsal or ventral myotomes. The recent finding that reticulospinal neurons, when stimulated individually during fictive locomotion, elicit distinct patterns of excitation and inhibition of the ventral root branches innervating dorsal or ventral muscles (Zelenin et al. 2001) suggests that each reticulospinal neuron is specialized for producing a particular motor synergy involved in the control of body movements of the lamprey. Thus, one might expect that the spinobulbar neurons provide specific ascending signals about spinal cord network function that are matched to the output function of the reticulospinal neurons as has been shown recently for vestibular input to reticulospinal neurons (Zelenin et al. 2007). By virtue of the relative simplicity of the ascending and descending systems, the lamprey nervous system may be amenable to investigating the basic organizational features of these systems in a vertebrate.

\section{Acknowledgments}

This work supported by NIH NS040755 to JTB.

Brain Research Reviews, Vol. 57, No. 1 (January 2008): pg. 37-45. DOI. This article is (C) Elsevier and permission has been granted for this version to appear in e-Publications@Marquette. Elsevier does not grant permission for this article to be further copied/distributed or hosted elsewhere without the express permission from Elsevier. 
NOT THE PUBLISHED VERSION; this is the author's final, peer-reviewed manuscript. The published version may be accessed by following the link in the citation at the bottom of the page.

Go to:

\section{Footnotes}

Publisher's Disclaimer: This is a PDF file of an unedited manuscript that has been accepted for publication. As a service to our customers we are providing this early version of the manuscript. The manuscript will undergo copyediting, typesetting, and review of the resulting proof before it is published in its final citable form. Please note that during the production process errors may be discovered which could affect the content, and all legal disclaimers that apply to the journal pertain.

Theme: Motor systems and sensorimotor integration

Topic: Spinal cord and brainstem

\section{References}

Arshavsky YI, Berkinblit MB, Fukson OI, Gelfand IM, Orlovsky GN. Recordings of neurones on the dorsal spinocerebellar tract during evoked locomotion. Brain Res. 1972a;43:272-275.

Arshavsky YI, Berkinblit MB, Fukson OI, Gelfand IM, Orlovsky GN. Origin of modulation in neurones of the ventral spinocerebellar tract during locomotion. Brain Res. 1972b;43:276-279.

Arshavsky YI, Gelfand IM, Orlovsky GN, Pavlova GA. Messages conveyed by spinocerebellar pathways during scratching in the cat. I. Activity of neurons of the lateral reticular nucleus. Brain Res. 1978a;151:479-491.

Arshavsky YI, Gelfand IM, Orlovsky GN, Pavlova GA. Messages conveyed by spinocerebellar pathways during scratching in the cat. II. Activity of neurons of the ventral spinocerebellar tract. Brain Res. 1978b;151:493-506.

Arshavsky YI, Gelfand IM, Orlovsky GN, Pavlova GA. Messages conveyed by descending tracts during scratching in the cat. I. Activity of vestibulospinal neurons. Brain Res. 1978c;159:99110.

Brain Research Reviews, Vol. 57, No. 1 (January 2008): pg. 37-45. DOI. This article is (C) Elsevier and permission has been granted for this version to appear in e-Publications@Marquette. Elsevier does not grant permission for this article to be further copied/distributed or hosted elsewhere without the express permission from Elsevier. 
Arshavsky YI, Orlovsky GN, Pavlova GA, Perret C. Messages conveyed by descending tracts during scratching in the cat. II. Activity of rubrospinal neurons. Brain Res. 1978d;159:111-123.

Arshavsky YI, Gelfand IM, Orlovsky GN. Cerebellum and Rhythmical Movements. Springer-Verlag; Berlin: 1986a.

Arshavsky YI, Orlovsky GN, Pavlova GA, Popova LB. Activity of C3-C4 propriospinal neurons during fictitious forelimb locomotion in the cat. Brain Res. 1986b;363:354-357.

Arshavsky YI, Orlovsky GN. Role of the cerebellum in the control of rhythmic movements. In: Grillner S, Stein PSG, Stuart DG, Forssberg $\mathrm{H}$, Herman RM, editors. Neurobiology of Vertebrate Locomotion. MacMillan; London: 1986. pp. 677-689.

Arshavsky YI, Orlovsky GN, Perret C. Activity of rubrospinal neurons during locomotion and scratching in the cat. Behav. Brain Res. 1988;28:193-199.

Bosco G, Poppele RE. Proprioception from a spinocerebellar perspective. Physiol. Rev. 2001;81:539-568.

Buchanan JT. Identification of interneurons with contralateral, caudal axons in the lamprey spinal cord: synaptic interactions and morphology. J. Neurophysiol. 1982;47:961-975.

Buchanan JT, Cohen AH. Activities of identified interneurons, motoneurons, and muscle fibers during fictive swimming in the lamprey and effects of reticulospinal and dorsal cell stimulation. J. Neurophysiol. 1982;47:948-960.

Buchanan JT. Contributions of identifiable neurons and neuron classes to lamprey vertebrate neurobiology. Prog. Neurobiol. $2001 ; 63: 441-466$.

Buchanan JT, Grillner S, Cullheim S, Risling M. Identification of excitatory interneurons contributing to the generation of locomotion in the lamprey: structure, pharmacology, and function. J. Neurophysiol. 1989;62:59-69.

Brain Research Reviews, Vol. 57, No. 1 (January 2008): pg. 37-45. DOI. This article is (C) Elsevier and permission has been granted for this version to appear in e-Publications@Marquette. Elsevier does not grant permission for this article to be further copied/distributed or hosted elsewhere without the express permission from Elsevier. 
NOT THE PUBLISHED VERSION; this is the author's final, peer-reviewed manuscript. The published version may be accessed by following the link in the citation at the bottom of the page.

Buchanan JT, Kasicki S. Activities of spinal neurons during brainstemdependent fictive swimming in lamprey. J. Neurophysiol. $1995 ; 73: 80-87$.

Bussières N, Dubuc R. Phasic modulation of vestibulospinal neuron activity during fictive locomotion in lampreys. Brain Res. $1992 ; 575: 174-179$.

Bussières N, Pflieger JF, Dubuc R. Anatomical study of vestibulospinal neurons in lampreys. J. Comp. Neurol. 1999;407:512-526.

Deliagina TG, Zelenin PV, Orlovsky GN. Encoding and decoding of reticulospinal commands. Brain Res. Rev. 2002;40:166-177.

Dubuc R, Grillner S. The role of spinal cord inputs in modulating the activity of reticulospinal neurons during fictive locomotion in the lamprey. Brain Res. 1989;483:196-200.

Einum JF, Buchanan JT. Reticulospinal neurons receive direct spinobulbar inputs during locomotor activity in lamprey. J. Neurophysiol. 2004;92:1384-1390.

Einum JF, Buchanan JT. Membrane potential oscillations in reticulospinal and spinobulbar neurons during locomotor activity. J. Neurophysiol. 2005;94:273-281.

Einum JF, Buchanan JT. Spinobulbar neurons in lamprey: cellular properties and synaptic interactions. J. Neurophysiol. 2006;96:2042-2055.

Grillner S, Williams T, Lagerback PA. The edge cell, a possible intraspinal mechanoreceptor. Science. 1984;223:500-503.

Guertin P, Dubuc R. Effects of stimulating the reticular formation during fictive locomotion in lampreys. Brain Res. $1997 ; 753: 328-334$.

Illert M, Lundberg A. Collateral connections to the lateral reticular nucleus from cervical propriospinal neurons projecting to

Brain Research Reviews, Vol. 57, No. 1 (January 2008): pg. 37-45. DOI. This article is (C) Elsevier and permission has been granted for this version to appear in e-Publications@Marquette. Elsevier does not grant permission for this article to be further copied/distributed or hosted elsewhere without the express permission from Elsevier. 
NOT THE PUBLISHED VERSION; this is the author's final, peer-reviewed manuscript. The published version may be accessed by following the link in the citation at the bottom of the page.

forelimb motoneurons in the cat. Neurosci. Lett. 1978;7:167172.

Kasicki S, Grillner S. Müller cells and other reticulospinal neurones are phasically active during fictive locomotion in the isolated nervous system of the lamprey. Neurosci. Lett. 1986;69:239243.

Kasicki S, Grillner S, Ohta Y, Dubuc R, Brodin L. Phasic modulation of reticulospinal neurones during fictive locomotion and other types of spinal motor activity in lamprey. Brain Res. 1989;484:203216.

Kimmel CB. Patterning the brain of the zebrafish embryo. Annu. Rev. Neurosci. 1993;16:707-732.

Lundberg A. Function of the ventral spinocerebellar tract: a new hypothesis. Exp. Brain Res. 1971;12:317-330.

Lundberg A, Weight F. Functional organization of connexions to the ventral spinocerebellar tract. Exp. Brain Res. 1971;12:295-316.

McClellan AD, Hagevik A. Descending control of turning locomotor activity in larval lamprey: neurophysiology and computer modeling. J. Neurophysiol. 1997;78:214-228.

Murakami Y, Pasqualetti M, Takio Y, Hirano S, Riji FM, Kuratani S. Segmental development of reticulospinal and branchiomotor neurons in lamprey: insights into the evolution of the vertebrate hindbrain. Development. 2004;131:983-995.

Ohta Y, Grillner S. Monosynaptic excitatory amino acid transmission from the posterior rhombencephalic reticular nucleus to spinal neurones involved in the control of locomotion in lamprey. J. Neurophysiol. 1989;62:1079-1089.

Orlovsky GN. Work of the reticulo-spinal neurons during locomotion. Biophysics. 1970a;15:761-771.

Brain Research Reviews, Vol. 57, No. 1 (January 2008): pg. 37-45. DOI. This article is (C) Elsevier and permission has been granted for this version to appear in e-Publications@Marquette. Elsevier does not grant permission for this article to be further copied/distributed or hosted elsewhere without the express permission from Elsevier. 
NOT THE PUBLISHED VERSION; this is the author's final, peer-reviewed manuscript. The published version may be accessed by following the link in the citation at the bottom of the page.

Orlovsky GN. Influence of the cerebellum on the reticulospinal neurons during locomotion. Biophysics. 1970b;15:928-936.

Orlovsky GN. Activity of vestibulospinal neurons during locomotion. Brain Res. 1972a;46:85-98.

Orlovsky GN. Activity of rubrospinal neurons during locomotion. Brain Res. 1972b;46:99-112.

Orlovsky GN, Deliagina TG, Grillner S. Neuronal Control of Locomotion. Oxford University Press; Oxford: 1999.

Ronan M, Northcutt RG. Projections ascending from the spinal cord to the brain in petromyontid and myxinoid agnathans. J. Comp. Neurol. 1990;291:491-508.

Rovainen CM. Physiological and anatomical studies on large neurons of central nervous system of the sea lamprey (Petromyzon marinus). I. Müller and Mauthner cells. J. Neurophysiol. 1967;30:1000-1023.

Rovainen CM. Synaptic interactions of identified nerve cells in the spinal cord of the sea lamprey. J. Comp. Neurol. 1974a;154:189-206.

Rovainen CM. Synaptic interactions of reticulospinal neurons and nerve cells in the spinal cord of the sea lamprey. J. Comp. Neurol. 1974b;154:207-223.

Swain GP, Snedeker JA, Ayers J, Selzer ME. Cytoarchitecture of spinalprojecting neurons in the brain of the larval sea lamprey. J. Comp. Neurol. 1993;336:194-210.

Vinay L, Bongianni F, Ohta Y, Grillner S, Dubuc R. Spinal inputs from lateral columns to reticulospinal neurons in lampreys. Brain Res. 1998a;808:279-293.

Vinay L, Bussières N, Shupliakov O, Dubuc R, Grillner S. Anatomical study of spinobulbar neurons in lampreys. J. Comp. Neurol. $1998 b ; 397: 475-492$.

Brain Research Reviews, Vol. 57, No. 1 (January 2008): pg. 37-45. DOI. This article is (C) Elsevier and permission has been granted for this version to appear in e-Publications@Marquette. Elsevier does not grant permission for this article to be further copied/distributed or hosted elsewhere without the express permission from Elsevier. 
NOT THE PUBLISHED VERSION; this is the author's final, peer-reviewed manuscript. The published version may be accessed by following the link in the citation at the bottom of the page.

Vinay L, Grillner S. Spino-bulbar neurons convey information to the brainstem about different phases of the locomotor cycle in the lamprey. Brain Res. 1992;582:134-138.

Wannier T, Deliagina TG, Orlovsky GN, Grillner S. Differential effects of the reticulospinal system on locomotion in lamprey. J. Neurophysiol. 1998;80:103-112.

Zelenin PV. Activity of individual reticulospinal neurons during different forms of locomotion in the lamprey. Euro. J. Neurosci. $2005 ; 22: 2271-2282$.

Zelenin PV, Grillner S, Orlovsky GN, Deliagina TG. Heterogeneity of the population of command neurons in the lamprey. J. Neurosci. 2001;21:7793-7803.

Zelenin PV, Pavlova EL, Grillner S, Orlovsky GN, Deliagina TG. Comparison of the motor effects of individual vestibulo- and reticulospinal neurons on dorsal and ventral myotomes in lamprey. J. Neurophysiol. 2003;90:3161-3167.

Zelenin PV, Orlovsky GN, Deliagina TG. Sensory-motor transformation by individual command neurons. J. Neurosci. 2007;27:10241032.

Brain Research Reviews, Vol. 57, No. 1 (January 2008): pg. 37-45. DOI. This article is C Elsevier and permission has been granted for this version to appear in e-Publications@Marquette. Elsevier does not grant permission for this article to be further copied/distributed or hosted elsewhere without the express permission from Elsevier. 